\title{
Adaptation Strategy of MSME (Micro, Small and Medium Enterprises) Actors in The Middle of Covid Pandemic (Study in Surabaya and Sidoarjo)
}

\author{
Diyah Utami \\ Sociology Program of Social Science Department Universitas Negeri Surabaya \\ e-mail: diyahutami@unesa.ac.id \\ Mutiah \\ Communication Program of Social Science Department Universitas Negeri Surabaya \\ e-mail: mutiah@unesa.ac.id \\ Arief Sudrajat \\ Sociology Program of Social Science Department Universitas Negeri Surabaya \\ e-mail: ariefsudrajat@unesa.ac.id
}

\begin{abstract}
This study aims to see the impact of the COVID pandemic on a group of people, namely MSME (Micro, Small and Medium Enterprises) actors. This entrepreneurial sector is known for its flexibility and resilience to withstand all situations and conditions, including during the 1998 monetary crisis. However, during the pandemic, this sector was hit the hardest compared to large companies. This is because the MSME sector in general does not have large savings as part of a precautionary motive. The government actually already has an assistance program for MSMEs affected by COVID. But, of course, MSME (Micro, Small and Medium Enterprises) actors must rise up to help themselves, not only relying on government programs that may have limitations. This study aims to see the strategies of the MSME actors, both economic and social strategies. Researches on the adaptive strategies of economic actors have indeed been carried out frequently. The difference is that the adaptive strategy that will be examined this time is a strategy during the COVID pandemic. Most of the COVID-19 studies have been conducted in the medical or health sector. Because this research was conducted during the pandemic, interviews were conducted through digital technology, namely WA calling or telephone. There were six research subjects who were interviewed, with various product variants produced. Based on the research results, it was found that there are three kinds of adaptation strategies for MSME actors namely: economic strategy, technology strategy and social network strategy.
\end{abstract}

Keywords: Adaptation Strategy, MSME (Micro, Small and Medium Enterprises) Actors, COVID Pandemic

\section{INTRODUCTION}

It is not only workers or employees who are feeling the impact of the COVID pandemic. Business owners also experience it, both large and small scale (MSMEs). MSMEs are actually the most flexible sector. This flexibility makes this sector adapt easily. During the monetary crisis in 1998, when large companies collapsed, the MSME sector was still surviving and had the ability to absorb labor compared to large companies. This pandemic is a serious blow to some MSMEs. Some MSMEs have indeed made high profits during the COVID-19 pandemic, for example the production and sale of medical devices (masks, disinfectants and hand sanitizers). Some sectors are 
trying to adapt to current conditions, for example the culinary sector. Some are difficult to adapt, so they are forced to switch to other sectors. For MSME owners, conditions will be even more difficult if there is no saving fund. Based on these circumstances, a fast program is needed to help MSMEs affected by COVID. For MSME owners, there are several programs that are being worked on by the government. Although there is a government assistance program scheme, MSME actors also need to develop an internal strategy to survive the crisis during this pandemic. This research focuses on MSME adaptation strategies, both economically and socially. This research is important to do because the condition of the MSME sector is weakening and the possibility of limited government programs in reaching MSMEs as a whole

\section{RESEARCH METHODS}

Type of this research is to categorize existing phenomena. The approach used is an entrepreneurial approach because in situations or conditions that are completely uncertain like pandemic situation, MSME actors must apply the right entrepreneurial strategy. The research locations are MSMEs in the cities of Surabaya and Sidoarjo. The reason for choosing locations in the two cities is because Surabaya and Sidoarjo are the two largest cities in East Java. The selection of research subjects was carried out by purposive sampling, the criteria are:

1. MSME actors who are in the category of adapting due to the decline in business turnover due to the COVID pandemic

2. Minimum age of MSMEs is two years, because at that age MSMEs are considered to be firmly established, so it needs to be studied more deeply if suddenly experiencing difficult times like now.

Researchers interviewed six research subjects with various business variants, namely juice suppliers for hotels, suppliers of dates and other Arabic products, suppliers of dishwashing sponges, suppliers of negligee and nightgowns, and suppliers of shoes.

\section{RESULT AND DISCUSSION}

Based on the observations of researchers, the adaptation strategies carried out by MSME actors are divided into three, namely economically, the use of information technology and also socially.

Economically in the form of business diversification / side jobs, Business diversification or a side job is considered capable of providing opportunities for earning a living, even though the profits are not as large as the main income. Meanwhile, laying off workers is the only way that can be taken due to the less income they get.

Technologically, many MSME actors feel helped by the 4.0 industrial revolution. Digital information technology is the choice of research subjects as part of their efforts to survive. This technology can be in the form of the use of social media (WA, marketplace and grab / gojek) to promote products. Technology expands and facilitates marketing reach in the marketing period. For customers, technology makes it easier to get the desired goods or services.

Socially, it is through the expansion of social networks in many ways. Social networks here can be in the form of friendships between MSME actors, fellow pupils, friendships during college, mosque organizations and also entrepreneurial organizations.

For MSMEs that have been affected by the pandemic, it seems that it is necessary to re-evaluate the results of their products. Evaluation is not only carried out when the business is established, but also needs to be done when the turnover of the business has 
decreased. One of the well-known evaluation methods is SWOT. In general, a SWOT analysis can be divided into two categories, namely external and internal factors. Internal factors are factors that originate in the business including strength and weakness, while external factors are factors that come from outside the business, including opportunities and threats. (Ayodya, 2019: 76). After conducting an evaluation, MSMEs can determine the right strategy, based on the strength of the capital they still have.

Economic or financial capital is associated with efforts to manage, increase, allocate and use funds owned as a monetary resource to obtain economic or social benefits through productive activities. Physical capital is more related to factors of production of goods or services, which in this context are raw materials and infrastructure to process them. Human capital is commonly associated with efforts to utilize intelligence, skills, levels and diversity of education and individual experiences. Social capital focuses on efforts to make use of social relations. (Usman, 2018: 3-4). For MSME actors, financial capital is certainly not as big as large companies. However, of course, MSMEs can still take advantage of their own capital and social capital. Selfcapital can be in the form of work ethic, skills, expertise and experience possessed by MSME actors. The work ethic referred to here is the attitudes that entrepreneurs have.

Without this attitude, social capital or financial capital is useless. Social capital is no less important than other capitals. Bjerke described the process of organizational change which initially depended heavily on bureaucracy, changed towards an outsourcing strategy, moved to focus on joint ventures, and nowadays organizational progress is more dependent on social networking factors. In the future, organizations are no longer dependent on orders, but more on an open system, namely social networks. (Storey in Bjerke, 2012: 142). It does not only happen to large organizations or companies, but also to smaller economic units, namely MSMEs. The social capital of MSMEs is in the form of relationships among MSME owners and also other social groups. The social groups that a person currently owns can be seen as membership in the WAG. The wider the social relations one has, the more membership in the WAG. Its WAG can be in the form of a network of family, friends, community, alumni of educational institutions and even a network of student guardians. This WAG media is then used as an economic channel, in terms of marketing products or partnering with fellow WAG members.

In fact, social networks that are formed in social media are dominated by weakties (Wei Wang, etc:2020). It is normal, due to the low intensity of direct social interactions which affects the closeness between users. Social media only helps strengthen existing social networks. Social media is difficult to rely on for its role to build new social networks, with high trust capital. Relationships between individuals are sometimes just impersonal, facilitated by the sophistication of digital technology. For example is the relationship between sellers and buyers in online transactions via the marketplace (Shopee, Tokopedia). Social interaction is only through chat rooms in applications that users rarely use. Sellers and buyers do not have the 'opportunity' to have personal relationships outside of online transactions, as is the case in the realm of conventional buying and selling. Transactions through Gojek / Grab companies are not much different. Social interactions between buyers and sellers are 'bridged' by drivers. There is no chat room between buyers and sellers. Even though the relationship is 'rigid', in a pandemic situation like this, digital technology is very helpful for MSMEs to survive. 
There are three types of social networks based on their levels, namely micro, meso and macro. The following is the analysis in this study:

1. Micro

Social network comes from the relationship of social interactions between individuals on a continuous basis. It can be seen from the relationship between MSME actors and buyers, who come from peers and their surrounding neighbors.

2. Meso

Social networks come from social relationships that exist in social groups. A concrete example in this research is the social relations in the WAG which is followed by MSME actors. This social network can take the form of paguyupan or patembangan.

Paguyuban networks are formal in the form, such as the Muslim entrepreneur organizations or cooperatives that Mr. Adnan is involved in. What is more likely is the social network model of paguyuban or non-formal, in the form of WAGs previously mentioned. Although the form is non-formal, this network provides many benefits to MSME players.

3. Macro

Social networks that exist between two groups or several groups. Because the form is still in the form of a micro-level business, the existence of the macro network has not been found in the context of this research.

Beside social networks, an important thing that really supports the existence of MSMEs in the midst of this pandemic is digital technology or social media, as part of the industrial revolution 4.0. Jacky Mussry mentioned the term UMKM 4.0, namely MSMEs that no longer play at a conservative level but must be able to see digital opportunities so that they can target a wider market. (Ayodya, 2019: 2008) The existence of the industrial revolution 4.0 can be said to be a catalyst in the COVID pandemic. It is unimaginable if there was no industrial revolution 4.0 at a time of a pandemic like this. The wheels of the MSME economy will certainly find it difficult to rotate, considering that there are restrictions in the form of physical distancing that make it difficult for offline transactions to occur. In normal times, mastery of technology 4.0 is very important for MSME players, especially during a pandemic like now.

All MSME business actors feel the same storm, it's just that the adaptability strategy of each business is different. Here are some interesting things that can be obtained from this research:

1. It is easier for food businesses to survive in this pandemic

2. If you more master in digital technology and have many social networks, the more you can adapt to situations and conditions.

3. Four research subjects whose the main job is entrepreneurship (husband and wife partner), one is a single parent with three children (Bu Nia, a cake seller) and the other is a clothes seller and pajama who has a husband with a ASN profession $(\mathrm{Bu}$ Yani). In the case of $\mathrm{Bu}$ Yani, it seems that the pandemic did not really have an impact on the family economy. Because Bu Yani's husband has a fixed salary as a civil servant and has a fairly high position in his institution, so $\mathrm{Bu}$ Yani doesn't have to try very hard learning to adapt like other research subjects. Bu Yani's source of income is her second source of income, after her husband's salary. It is different from other subjects, whose main source of income is entrepreneurship.

Large companies that have a lot of savings, of course, have a stronger endurance. 
However, for MSME practitioners, with not too large savings, holding hands together to survive in the midst of a pandemic is very crucial.

\section{CONCLUSION}

Seeing the fact that none of the MSMEs in this study received social assistance from the government, the suggestion that can be given is the government's attention to MSME actors in pandemic conditions. This form of attention is not only in the form of capital assistance, but can be in the form of online training related to adaptation strategies during a pandemic. In order to be right on target, the forms of social assistance should be sorted based on the needs of MSMEs. MSME that can still survive, the form of social assistance can only be in the form of training. Meanwhile, for the slumped MSMEs, the social assistance could be in the form of capital and training.

\section{REFERENCES}

Ayodya, Wulan. 2020. UMKM 4.0. Strategi UMKM Memasuki Era Digital. Jakarta.

Bjerke,Bjorn. 2007. Understanding Entrepreneurship. Edward Elgar Publishing, INC. UK

Damsar. 2009. Pengantar Sosiologi Ekonomi. Kencana Prenada Group. Jakarta Usman, Sunyoto. 2018. Modal Sosial. Pustaka Pelajar. Jakarta

Goh Brenda and Thomas Suen. 2020. Chinas Wuhan Lockdown Ends, But Another Begins As Local Coronavirus Cases Rise (The Jakarta Post. Diakses 10 April 2020)

https://www.bbc.com/indonesia/indonesia-52434794

https://www.bi.go.id/umkm/penelitian nasional/kajian/dokuments/profil bisnis UMKM.pdf. Diakses 13 Mei 2020

(https://www.cnnindonesia.com/ekonomi/2020041318022 5-532- 493152/kemenkopukm- rilis-e-form-data-umkm-terdampak-covid-19) . Diakses 13 Mei 2020

https://www.urbandictionary.com/define.php?term=WFH

(https://nasional.kompas.com/read/2020/04/15/17155131/pemerintah-siapkan-

2skemabantuan-bagi-umkm-yang-terdampak-wabah-covid-19\#). Diakses 1 Juni 2020

https://www.worldometers.info/coronavirus/country/us/

Papadopoulosa, Thanos.etc. 2020. The Use of Digital Technologies by Small and Medium Enterprises During COVID-19: Implications for Theory and

Practice. (Online).International Journal of Information Managemen (https://www.sciencedirect.com/science/article/pii/S02684 01220310549

Putsanra, Dipna. "Arti PSBB yang Dibuat untuk Cegah Penyebaran Corona di Indonesia"( https://tirto.id/eMXT. Diakses 13 April 2020)

Scarborough, Nourman and Jeffrey Cornwall. 2015. Entrepreneurship and Business Small Managemen. Pearson

Tran, Bach. 2020. Characterize Health And Economic Vulnerabilities Of Workers To Control The Emergence Of COVID-19 In An Industrial Zone In Vietnam. (Online) (https://www.sciencedirect.com/science/article/pii/S09257 53520302083)

Mashud, Mustain dan Udji Aisyah.2015. Pemberdayaan UMKM Yang Ditekuni Keluarga Miskin Pasca Terjadinya Bencana. Lembaga Penelitian dan Pengabdian Kepada Masyarakat Unair. Surabaya 
Wang, Wei.Etc.2020. Entrepreneurial Entry: The Role of Social Media.(Online) Journal Technologic Foresting and Social Change.Vol 161. (https://www.sciencedirect.com/science/article/pii/S004016 252031163X.) 